\title{
Who do we think we are: interdisciplinary dissonance and the development of professional identity
}

Judith Barbaro-Brown

From Society of Chiropodists and Podiatrists Annual Conference 2010

Bournemouth, UK. 21-23 October 2010

The development of professional identity is something which all students entering a vocational profession will encounter, and this is particularly so within health care where health professionals are expected to work as part of a team rather than as individual and isolated practitioners. Alongside this, students will develop perceptions relating to the roles, responsibilities, and even behaviours of other team members, influenced by personal experience, social background, and the media. This is referred to as 'construction of the other' (Lingard et al, 2002), and it appears that once these constructs or impressions are formed, they are difficult to change. In some health provision situations there appears to be a divergence in these perceptions between team members which can lead to inter-disciplinary conflict, thereby potentially impacting on team performance. If a better understanding could be gained of how professional identity begins to develop in the early years of health-care/ medical education, particularly in relation to the 'self' and the 'other', then perhaps educational strategy could be adapted and enhanced to help students and newlyqualified practitioners overcome potential difficulties when faced with working within the multi-disciplinary team. This paper aims to examine the influences which encourage the development of professional identity, and to discuss how educational strategy can be used to overcome this.

\section{Published: 20 December 2010}

\section{Reference}

1. Lingard L, Reznick R, De Vito I, Espin S: Forming professional identities on the healthcare team: discursive constructions of the 'other' in the operating room. Medical Education 2002, 36:728-734.

Durham University, Durham, UK
doi:10.1186/1757-1146-3-S1-O3

Cite this article as: Barbaro-Brown: Who do we think we are: interdisciplinary dissonance and the development of professional identity. Journal of Foot and Ankle Research 2010 3(Suppl 1):O3.
Submit your next manuscript to BioMed Central and take full advantage of:

- Convenient online submission

- Thorough peer review

- No space constraints or color figure charges

- Immediate publication on acceptance

- Inclusion in PubMed, CAS, Scopus and Google Scholar

- Research which is freely available for redistribution
() Biomed Central

\section{Biomed Central}

(c) 2010 Barbaro-Brown; licensee BioMed Central Ltd. This is an open access article distributed under the terms of the Creative Commons Attribution License (http://creativecommons.org/licenses/by/2.0), which permits unrestricted use, distribution, and reproduction in any medium, provided the original work is properly cited. 